and the central problem of whether primary psychosomatic disease exists. Nevertheless the significant emotional factors relating to psychosomatic illness noted in the literature were investigated and found not to apply to any important degree. We do, therefore, raise the question whether the disease should be regarded as psychosomatic in any way.

\section{BIBLIOGRAPHY}

Acheson, E. D. (1960). Gut, 1, 291.

(1965). Chapter 11 in Badenoch and Brooke (1965)

(1963). Gastroenterology, 44,7.

Arieti, S (1959). American Handbook of Psychiairy. New York.

Armitage, G., and Wilson, M. (1950) Brit. F. Surg., 38, 182.

Atwell, J. D., Duthie, H. L., and Goligher, J. C. (1965). Ibid., 52, 966

Arlett S. O. (1966). Brit med Goligher,

Badenoch. J., and Brooke, B. N. (1965). Recent Advances in Gastroenterology. Boston.

Bahn, A. K., Gardner. E. A., Alltop, L., Knatterud, G. L., and Solomon, M. (1967). Amer. f. publ. Hlth, 56, 2033.

Bargen, J A. (1955). Wis. med. f., 54, 367

(1966). Dis. Colon Rect., 9. 13.

Beeson, P. B., and McDermott, W. (editors) (1967). Cecil-Loeb Textbook of Medicine, 12th ed. 1967.

Blackburn. G., Hadfield, G., and Hunt, A. H. (1939). St. Bart. Hosp. Rep., 72, 181.

Bockus, H. L. (1945). I Amer. med. Ass., 127, 449.

(1965). Gastroenterology, 2nd ed., vol. 3. Philadelphia.

Cave, H.W. (1945). F. Amer. med Ass., 127, 208.

Colcock, B. P., and Vansant, J. H. (1960). Lahey Clin. Bull., 12, 53

Cooke, W. T., and Brooke, B. N. (1955). Quart. F. Med., 24, i.

Crocket, R. W. (1952). Lancet, 1, 946.

Crohn, B. B. (1965). Dis. Colon Rect., 8, 3.

and Yarnis, H. (1958). Regional lleitis, 2nd ed. New York

Dashiell, G G., Kirsner, J. B., Klotz, A. B., and Palmer, W. L. (1951) Med. Clin. N. Amer., 35, 227.

Dennis, C., and Eddy, F. D. (1947). Proc. Soc. exp. Biol. (N.Y.), 65, 306

Dragstedt, L. R., and Owens, F. M., jun. (1943). Ibid., 53, 152.

Edwards, F. C., and Truelove, S. C. (1964). Gut, 5, 1.'

Eisenstadt, H. B. (1965a). Amer. F. Gastroent., 43, 560.

- (1965b). Amer f. Prociol., 16, 370.

Essen-Möler, E. (1956). Acta psychiat. scand., Suppl. No. 100

Feldman, F., Cantor, D., Sull, S., and Bachrach, W. (1967). Brit. med. $7 ., 3,14$

Flanagan, J. C. (1964). Sth. med. f. (Bgham, Ala.), 57, 801.

Grace. W. J. (1953). Gastroenterology, 23, 542.

Hendrix, T. (1964). Chapter 4 in Mellinkoff (1964).
Hunt, T. (1965). Trans. med. Soc. Lond., 81, 87.

Janowitz, H. D. (19,5). F. Mi Sinai Hosp., 22, 223

Kaelbling, R., and Patterson, R. M. (1966). 'Eclectic Psychiatry. Springfield, III.

Kiefer, E. D. (1953). Lahey Clin. Bull., 8, 149.

Kraft, I. A., and Ardali, C. (1964). Sth. med. F. (Bgham, Ala.), 57, 799.

Leighton, D. C., Harding, J. S., Macklin, D. B., Macmillan, A. M., and Leighton, A. H. (1963). The Character of Danger. New York.

Lumb, G. (1951;. Brit. 7. Surg., 39, 233.

McBride, J. A., King, M. J., Baikie, A. G., Crean, G. P., and Sircus, W. (1963). Brit. med. F., 2, 483.

McConnell, R. B. (1965). Chaprer 1 in Badenoch and Brooke (1965).

Machella, T. E. (1966). In Principles of Internal Medicine, edited by T. R. Harrison. R. D Aaams, I. L. Bennett, W. H. Resnik, G. W. Thorn, and M. M. Wintrobe. New York.

Maddison, T. G., and Hyde, I. (1935). Arch. Dis. Childh., 30, 469.

Marshall, S. F., and Mathieson, W. L. (1955). Lahey Clin. Bull., 9, 66.

Mellinkoff, S. M. (editor) (1964). Differential Diagnosis of Diarrhea. New York.

Mersereau, B. S. (1963). Amer. ₹. Psychiat., 119, 1099.

Moseley, J. F., Marshak, R. H., and Wolf, B. S. (1960). Amer. Y. Roentgenol., 84, 532

Paulley, J. W. (1948). Lancet, 1, 923.

Paulley, (1949). Proc. roy. Soc. Med., 42, 241 (1959). Proc. roy. Soc. Med., 42, (1956). Lancet, 2, 215

Phear, D. (1958). Ibid., 2, 1250

Porritt, A., and Hunt, T C. (1960). Proc. roy. Soc. Med., 53, 373.

Pumphrey, R. E. (1938). Proc. Mayo Clin., 13, 539.

Richman, A. (1955). 7. Mt Sinai Hosp., 22, 175.

Ross, S. T. (1965). Surgery, 58, 357.

Schepers, G. W. H. (1945). Amer. $\dot{f}$. dig. Dis., 12, 97.

Schepers, G. W. Hn. Paediat. (Basel), 165, 281.

Sherlock, P., Bell, B. M., Steinberg, H., and Almy, T. P. (1963). Gastroenterology, 45, 413 .

Sperling, M. (1960). Int. f. Psycho-Anal., 41, 612.

Srole, L., Langner, T. S., Michael, S. T., Opler, M. K., and Rennle, T. A. C. (1962). Mental Health in the Metropolis. New York.

Stewart, W. A. (1949). N.Y. St. F. Med., 49, 2820

Storrs, R. C., and Hoekelman, R. A. (1953). New Engl. F. Med., 248, 320

Strömbeck, J. P. (1937). Acta chir. scand., 80, Suppl. No. 50, 1.

Tallroth, A. (1943). Ibid., 88, 407.

Taylor, K. (1965). Chapter 2 in Badenoch and Brooke (1965).

Turner, D A. (1953). Univ. W. Ont. med. ₹., 23, 160.

Turner, D A. (1953). Univ. W. Ont. med. f., 23, 160 . an Patter, W. N., Bargen. J. A., Dockerty, M. B., Feldman, W. H.,
Mayo, C. W., and Waugh, J. M. (1954). Gastroenterology, 26, 347. Walter, L. E., and Chaffin, L. (1957). West. F. Surg., 65, 354

Warren, R., and Miller, R. H. (1942). New Engl. J. Med., 226, 589.

Winkelman, E. I. (1967). Pediat. Clin. N. Amer., 14, 141.

Yarnis, H. (1955). 7 Mt Sinai Hosp., 22, 159.

Zetzel, L. (1967) In Cecil-Loeb Textbook of Medicine, edited by P. B. Beeson and W. McDermot.

\title{
Evaluation of a Screening Survey for Anaemia in Adult Non-pregnant Women
}

\author{
P. C. ELWOOD,* M.D., D.P.H., D.C.H. ; W. E. WATERS,* M.B., B.S., D.I.H. ; W. J. GREENE,* M.B., CH.B. \\ M. M. WOOD, $\dagger$ B.SC.
}

WITh THE Assistance of E. H. EVANS, $\ddagger$ M.D., M.R.C.P., J. DE SWIET, $\ddagger$ M.D., M.R.C.P., AND J. V. WILLIAMS, $\ddagger$ M.B., M.R.c.P.

Brit. med.F., 1967, 4, 714-717

Considerable interest has been shown recently in community health screening (Backett, 1960 ; Wilson, 1963 ; Acheson, 1963 ; Horne, Clark, and Patterson, 1967). The value of any healthscreening procedure depends both on the proportion of persons detected with the disease (or diseases) being sought, or with treatable associated conditions, and on the importance to life or health of these conditions. The number of affected persons detected is dependent both on the prevalence of the disease, or the conditions associated with it, in the community to which screening is offered, and on the nature and extent of selection, if any, of those members of that community who co-operate. In fact very little is known about the selection of persons who readily co-operate in health-screening procedures except in a very few situations, such as mass miniature radiography (Brad-

- From the Epidemiological Research Unit of the Medical Research Council, Cardiff.

† External Staff, Medical Researcn Council, Llandough Hospital, Penarth. $\ddagger$ Physicians, Liwynypia Hospital, Rhondda. bury, 1948) and cervical cytology (Wakefield and Barić, 1965), in both of which it seems that affected individuals are, on average, less likely to co-operate than those who are unaffected, though in coal-workers' pneumoconiosis (Cochrane, 1951) and possibly in other compensatable industrial diseases the reverse is probably true. Other than in a few such cases very little is known about how persons who spontaneously attend community screening clinics differ from other members of the community.

Assessment of the importance of the conditions detected during a screening survey necessitates value judgements which are not easily made and which ideally should be based on data relating to changes in the subsequent mortality or morbidity in the community screened. In the haematological community study described here the initial survey was evaluated as an ad hoc health-screening procedure. This evaluation was based on the following: (1) the proportion of subjects seen who were thought to be "anaemic," (2) the symptomatic benefit which resulted from iron therapy in these subjects, and (3) the pre- 
valence of serious underlying conditions detected in subjects believed to be anaemic.

In addition, the opportunity was taken to study some aspects of the selection of subjects who spontaneously attend a community health-screening survey. This was based on comparisons of the distributions of certain haematological and other variates, including symptomatology, in almost all the adult women in the geographically defined area selected for the survey with the same data in a large group of women of the same age who lived in immediately adjacent areas and who, without being contacted by the survey team, spontaneously attended the survey clinic.

The screening survey on which this report is based was confined to adult women. It was conducted as one of a series of studies of epidemiological aspects of iron deficiency. These studies included an examination of the symptoms associated with low haemoglobin levels and the effect of iron therapy on symptoms ; an examination of the symptomatic benefit of iron therapy in women with "normal" haemoglobin levels who complained of excessive fatigue; an evaluation of the part played in iron deficiency by dietary intake and menstrual loss of iron; and studies relevant to the prevention of iron deficiency in the community.

\section{Method}

An area in the Rhondda Fawr, an industrial valley in South Wales, was defined, and all female residents aged 20 to 64 years (inclusive) were visited and invited to attend a clinic. At the clinic a questionary was administered which covered certain aspects of symptomatology and general health, and the number of visits paid to a general practitioner during several intervals before the survey. Measurements were made of height, weight, triceps skin-fold thickness, and one simple aspect of lung function (the peak expiratory flow rate, as recorded on a Wright Peak Flow Meter). A sample of venous blood was taken for estimations of haemoglobin level and packed cell volume, and, in those found to have a haemoglobin level below $12 \mathrm{G}$., a blood film was examined. Haemoglobin level was estimated as cyanmethaemoglobin, and is expressed here as G. (grammes of haemoglobin per $100 \mathrm{ml}$. of blood). Packed cell volume (P.C.V.) was estimated by a microhaematocrit method.

On leaving the clinic a self-administered questionary was given to each woman, together with a stamped addressed envelope for its return. This was a modified version of the one described by Wood and Elwood (1966), and enabled six of the symptoms commonly attributed to iron-deficiency anaemia to be graded on seven point scales. In addition, this questionary contained two series of 10 questions in random order. One series related to symptoms or signs commonly believed to occur in iron-deficiency anaemia ; the other 10 were similar to questions in the Cornell Medical Index which have been used in community studies of psychoneurosis by Rawnsley (1966), Abramson, Terespolsky, Brook, and Kark (1965), and others. These latter questions were used here to give a measure of psychoneurosis in each subject.

The general practitioners in the area were visited, and with their permission all women with haemoglobin levels below $10 \mathrm{G}$. who were not already on treatment were offered referral to a local hospital outpatient clinic for examination and investigation by a consultant physician. The women with haemoglobin levels between 10 and $12 \mathrm{G}$. who were not already on treatment were questioned in a conventional clinical interview about symptoms which might indicate serious underlying disease, and then, together with those with levels below $10 \mathrm{G}$., were screened for occult blood in three faecal specimens by Hematest. In an attempt to evaluate the relevance of these results to anaemia a representative sample of an almost equal number of women with haemoglobin level of $12 \mathrm{G}$. and above were also screened in the same way for occult blood.
Women with haemoglobin levels between 8 and $12 \mathrm{G}$. who were not already on treatment were admitted to a clinical trial of the effects on symptoms of iron therapy $(200 \mathrm{mg}$. of elemental iron as ferrous carbonate in Ferrodic per person per day for eight weeks). This study was very similar to the one described by Elwood and Wood (1966), and detailed results will be published elsewhere. Only data from this trial which are relevant to the evaluation of the basic screening survey are referred to here.

In an attempt to ascertain factors which might be relevant to the selection of persons who spontaneously attend a community health survey clinic comparisons were made between the distributions in the basic population and the spontaneous attenders (these groups are defined below) of a large number of attributes and variates, including age, parity, haemoglobin level and P.C.V., height, weight, skin-fold thickness, symptoms (including the neurotic grade described above), and estimates of the number of visits paid to a general practitioner during one week, one month, and one year immediately before the survey.

\section{Results}

During the survey 1,138 women were seen. Nine hundred and twenty were residents in the defined area and were aged 20-64 years ; 19 of these were pregnant and are omitted from all subsequent discussion. The others are subsequently referred to here as "the basic population." The remaining 218 women seen were either outside the age limits of the study or were residents in surrounding areas who were not visited or contacted in any way by the survey team but heard about the survey and attended the survey clinic spontaneously. The 180 of these who were aged $20-64$ years are subsequently referred to here as "the spontaneous attenders." Those who were outside 20-64 years of age have been excluded from all that follows. Table I summarizes all these data and incidentally shows some evidence of a relative deficiency of women in the younger age groups, probably due to migration out of the area.

TABLB I.-Distributions by Age of Basic Population and Spontaneous

\begin{tabular}{|c|c|c|c|c|}
\hline \multirow{2}{*}{ Age } & \multicolumn{3}{|c|}{ Basic Population } & \multirow{2}{*}{$\begin{array}{l}\text { Spontaneous } \\
\text { Attenders }\end{array}$} \\
\hline & Total & Seen & Refused & \\
\hline $\begin{array}{l}15- \\
20- \\
30- \\
40- \\
50- \\
60- \\
65+\end{array}$ & $\begin{array}{r}\overline{6} \\
81 \\
110 \\
140 \\
143 \\
114 \\
105 \\
118 \\
128 \\
-\end{array}$ & $\begin{array}{l}\overline{64}(11) \\
77(1) \\
102(4) \\
128(1) \\
132(2) \\
107 \\
96 \\
105 \\
109 \\
-\end{array}$ & $\begin{array}{c}- \\
2(3.0 \%) \\
4(4.9 \%) \\
8(7.3 \%) \\
12(8.6 \%) \\
11(7.7 \%) \\
7(6.1 \%) \\
9(8.6 \%) \\
13(11.0 \%) \\
19(14.8 \%) \\
-\end{array}$ & $\begin{array}{r}18 \\
13 \\
11 \\
26 \\
24 \\
30 \\
24 \\
20 \\
25 \\
7 \\
20\end{array}$ \\
\hline Total & 1,005 & $920(19)$ & $85(8.5 \%)$ & 218 \\
\hline
\end{tabular}

Women outside age limits of studv (20-64 years) rokether with innse who were pregnant (shown in parentheses) omitted from $\chi^{2}$ tests and all subsequent discussion.
Basic population aeen and spontaneous artenders: $x^{2}=13 \cdot 28$ : D.F. $=8$ :
$0.2>P>0.1$.

Basic population seen and refusals: $x^{2}=12.46$; D.P. $=7$; $0.1>P>0.05$

The distributions of the basic population and the spontaneous attenders by haemoglobin level and P.C.V. are shown in Table II. There is no evidence of a significant difference (at $\mathrm{P}<0.05$, the criterion of significance used throughout) in the distributions of these variates in the two populations. No case of megaloblastic anaemia was detected.

There were $31(3.4 \%)$ women in the basic popliation and $13(7.2 \%)$ in the spontaneous attenders who had haemoglobin levels below $10 \mathrm{G}$. These proportions do not differ significantly. Thirty-seven of these were not already under treatment for anaemia, and agreed to referral to hospital outpatient departments for further examination and investigation. In nine cases $(0.8 \%$ of all the women) further action relevant to the irondeficiency anaemia was taken. One woman had haemorrhoids injected, six had uterine dilatation and curettage, one who could 
not tolerate oral iron was admitted to hospital for blood transfusion, and one was found on routine $x$-ray examination to have an opacity in her chest, which was removed and found to be a carcinoid adenoma.

TABLE II.-Distribution of Basic Population and Spontaneous Attenders by Haemoglobin Level and Packed Cell Volumes

\begin{tabular}{|c|c|c|c|c|c|}
\hline \multicolumn{3}{|c|}{ Hremoglobin Level } & \multicolumn{3}{|c|}{ Packed Cell Volume } \\
\hline G. & $\begin{array}{c}\text { Basic } \\
\text { Population }\end{array}$ & $\begin{array}{c}\text { Spontaneous } \\
\text { Attenders }\end{array}$ & $\%$ & $\begin{array}{c}\text { Basic } \\
\text { Population }\end{array}$ & $\begin{array}{c}\text { Spontaneous } \\
\text { Attenders }\end{array}$ \\
\hline $\begin{array}{r}6.5 \\
7.0 \\
7.5 \\
8.0 \\
8.5 \\
9.0 \\
9.5 \\
10.0 \\
10.5 \\
11.0 \\
11.5 \\
12.0 \\
12.5 \\
13.0 \\
13.5 \\
14.0 \\
14.5 \\
15.0 \\
15.5 \\
16.0 \\
16.5 \\
17.0 \\
17.5 \\
18.0 \\
18.5 \\
\end{array}$ & $\begin{array}{r}-3 \\
4 \\
7 \\
4 \\
5 \\
8 \\
9 \\
18 \\
14 \\
22 \\
50 \\
67 \\
144 \\
194 \\
143 \\
116 \\
44 \\
28 \\
10 \\
7 \\
3 \\
1 \\
\end{array}$ & $\begin{array}{r}1 \\
\overline{1} \\
\frac{1}{1} \\
10 \\
2 \\
2 \\
4 \\
5 \\
9 \\
12 \\
21 \\
36 \\
35 \\
26 \\
8 \\
3 \\
2 \\
= \\
= \\
=1\end{array}$ & $\begin{array}{l}26 \\
27 \\
28 \\
29 \\
30 \\
31 \\
32 \\
33 \\
34 \\
35 \\
36 \\
37 \\
38 \\
39 \\
40 \\
41 \\
42 \\
43 \\
44 \\
45 \\
46 \\
47 \\
48 \\
49 \\
50+\end{array}$ & $\begin{array}{r}2 \\
1 \\
3 \\
6 \\
4 \\
1 \\
6 \\
7 \\
14 \\
22 \\
18 \\
40 \\
71 \\
107 \\
121 \\
116 \\
123 \\
94 \\
52 \\
37 \\
12 \\
14 \\
5 \\
5 \\
5\end{array}$ & $\begin{array}{r}- \\
1 \\
1 \\
1 \\
2 \\
2 \\
10 \\
6 \\
4 \\
7 \\
5 \\
19 \\
15 \\
31 \\
13 \\
22 \\
18 \\
8 \\
5 \\
3 \\
1 \\
1 \\
=\end{array}$ \\
\hline $\begin{array}{l}\text { Total } \\
\text { Mean } \\
\text { S.E. }\end{array}$ & $\begin{array}{r}901 \\
13.32 \\
0.05\end{array}$ & $\begin{array}{r}179 \\
13.45 \\
0.12\end{array}$ & $\begin{array}{l}\text { Total } \\
\text { Mean } \\
\text { S.E. }\end{array}$ & $\begin{array}{r}886^{\circ} \\
40.49 \\
0 \cdot 12\end{array}$ & $\begin{array}{r}175^{\circ} \\
40.00 \\
0.28\end{array}$ \\
\hline
\end{tabular}

* Several estimations inadvertently omitted.

The 63 women in the basic population and the 13 of the spontanenus attenders who had haemoglobin levels between 10 and $12 \mathrm{G}$. were visited in their homes and questioned in a conventional clinical interview. In a very few cases symptoms were elicited that were suggestive of underlying conditinns (such as haemorrhoids, etc.), but in no case in which these symptoms might have been relevant to the iron-deficiency anaemia were they thought to be severe enough to warrant the initiation of further investigations.

There were 120 women with haemoglobin levels below $12 \mathrm{G}$. These were all asked to supply three specimens of faeces for testing for occult blood, except 10 women whom it was thought injudicious to include in this part of the study, as they were already receiving iron therapy from their general practitioners. Of the other women 19 refused and 91 ( $83 \%$ ) each supplied three specimens. These data, together with the results of Hematest examinations by two independent observers, are shown in Table III. One or more samples from 15 subjects $(16 \%$ of those tested) gave a definite positive result, though only in four $(4 \%)$ was there agreement between the two observers. There is no evidence of any association between the proportion of positive results with haemoglobin level. Indeed, none of the seven with levels below $8 \mathrm{G}$. who were tested had evidence of faecal occult blood. A representative sample of 69 women with haemoglobin levels above $12 \mathrm{G}$. were contacted, and the 64 $(93 \%)$ who co-operated were tested in the same way. Of these, five $(8 \%)$ gave a positive result, and, though this is lower than

TABLE III.-Details of Samples Tested by Hemastet for Faecal Occult TABLE Ilood on Three Occasions by Two Independent Observers

\begin{tabular}{|c|c|c|c|c|c|c|c|c|}
\hline \multirow{3}{*}{$\underset{\text { Level }}{\mathrm{Hb}}$} & \multirow{3}{*}{$\begin{array}{c}\text { No. } \\
\text { Identified } \\
\text { During } \\
\text { Screening }\end{array}$} & \multirow{3}{*}{$\begin{array}{c}\text { On Iron } \\
\text { Therapy } \\
\text { from G.P. } \\
\text { (etc.) }\end{array}$} & \multirow{3}{*}{ Refused } & \multirow{3}{*}{$\begin{array}{l}\text { Total } \\
\text { Tested }\end{array}$} & \multicolumn{4}{|c|}{ Results of Hematest } \\
\hline & & & & & \multicolumn{2}{|c|}{ Negative } & \multirow{2}{*}{$\begin{array}{c}\text { Doubt- } \\
\text { ful }\end{array}$} & \multirow{2}{*}{ Positive } \\
\hline & & & & & No. & $\%$ & & \\
\hline $\begin{array}{c}<8 \\
8-10 \\
10-12\end{array}$ & $\begin{array}{r}8 \\
36 \\
76 \\
\end{array}$ & $\begin{array}{l}-3 \\
7 \\
\end{array}$ & $\begin{array}{r}1 \\
4 \\
14 \\
\end{array}$ & $\begin{array}{r}7 \\
29 \\
55 \\
\end{array}$ & $\begin{array}{r}7 \\
22 \\
45 \\
\end{array}$ & $\begin{array}{r}100 \\
76 \\
82 \\
\end{array}$ & $\frac{\bar{z}}{2 \overline{(}-)}$ & $\begin{array}{l}7(1) \\
8(3)\end{array}$ \\
\hline Total & 120 & 10 & 19 & 91 & 74 & 81 & $2(-)$ & $15(4)$ \\
\hline $12+$ & \multicolumn{3}{|c|}{$\begin{array}{c}\text { Representative sample of } 69 \\
\text { women }\end{array}$} & 64 & 58 & 91 & $1(-)$ & $5(3)$ \\
\hline
\end{tabular}

No. of tests in which there was agreement between the two observers shown in parentheses. the proportion in women with haemoglobin levels below $12 \mathrm{G}$. found to be positive, it does not differ from it significantly. Each of the 20 women with a positive result was visited again, asked about rectal bleeding, and asked to supply a further three faecal specimens. Eight said they had haemorrhoids which bled occasionally, and faecal specimens from four of these gave a second positive Hematest. Other than these none of the women had a second positive test.

Almost all the women with haemoglobin levels between 8 and $12 \mathrm{G}$. were admitted to the clinical trial of the effect of iron therapy on symptoms. Detailed results will be presented elsewhere; suffice to say here that there was no evidence of a beneficial effect of eight weeks of conventional iron therapy on the symptoms of irritability, palpitations, dizzinesses, breathlessness, fatigue, or headache which was greater than that of identical placebo tablets which contain no iron.

There were no significant differences between the basic population and the spontaneous attenders in any attribute or variate measured, other than in weight. The spontaneous attenders were $6.8 \pm 2.1 \mathrm{lb}$. $(3.1 \pm 0.95 \mathrm{~kg}$.) heavier on average than the basic population. Apart from this difference the two groups were homogeneous with respect to age, parity, height,

TABLE IV.-Summary of Comparisons Between Spontaneous Attenders

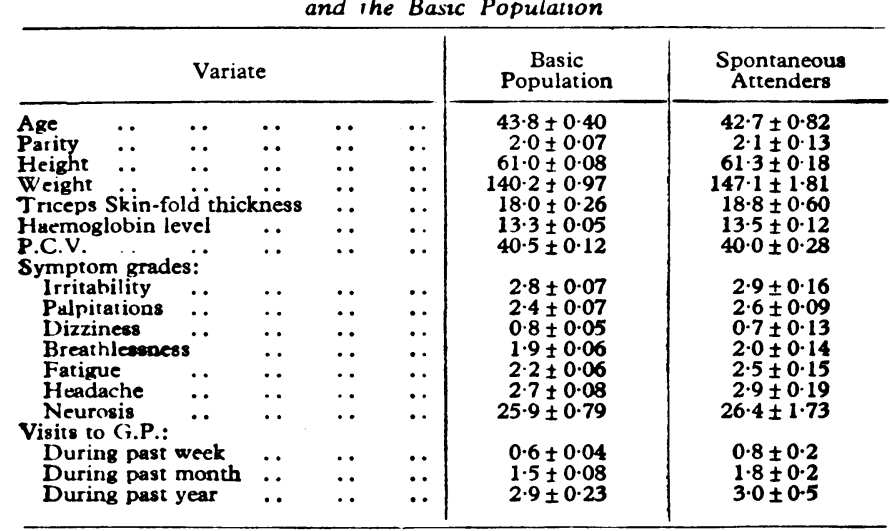

triceps skin-fold thickness, haemoglobin level, P.C.V., symptom grades, and their own estimates of the number of visits to a general practitioner during one week, one month, and one year immediately before the survey (Table IV).

\section{Discussion}

Screening for disease should be regarded as one step in the diagnostic process and not as an end in itself. Thus a general practitioner seeing his surgery attenders, or a consultant physician his outpatients, are simply forms of screening and fundamentally differ little from community screening procedures. However, a realistic evaluation of any screening procedure cannot be made without consideration of the benefit, if any, which results from the screening, and this aspect often seems to be ignored-for example, by Horne et al. (1967) in their report of a local health authority screening survey. Acheson (1963) lists five criteria which ideally should be fulfilled before any healthscreening procedure is instituted, and similar criteria are incorporated in the discussion by Wilson (1963). These criteria include matters relating to the prevalence of the condition being sought, its importance, the sensitivity and specificity of the tests required for its diagnosis, the acceptahility of this test by the subjects screened, and the acceptability and effectiveness of treatment available for those found to have the condition sought. Few diseases, if any, fully meet all the criteria outlined, but Acheson (1963) specifically mentions anaemia as probably fulfilling all the criteria except perhaps those relating to its importance in terms of morbidity and mortality. 
Our study, however, appears to us to give very little encouragement for community health screening for anaemia. Though a fairly high proportion of women were detected with haemoglobin levels below commonly accepted lower limits of normal, thus being consistent with data obtained in the community surveys of Kilpatrick (1961), Elwond (1964), and others, yet the importance of " anaemia," so defined, appears to be relatively small. This assessment of importance is based both on the apparent absence of serinus treatable underlying conditions in the subjects with the lowest haemoglobin levels and on the absence of unequivocal benefit in the symptoms of those treated with iron. Even in those in whom further action was taken, in only one was there evidence of serious disease, and this was almost certainly a chance finding, unrelated to the anaemia. Furthermore, the relevance to anaemia of the other conditions treated-haemorrhoids and menorrhagia-and the success of the treatment given, can strictly only be assumed, as we made no quantitative measurements of blood loss.

It might be argued that our subjects were not investigated with sufficient thoroughness to detect all serious underlying disease. In particular it could be pointed out that all the subjects whose faecal specimens were positive to Hematest were not exhaustively investigated. This criticism is valid, but one of the main aims of this survey was to evaluate the existing facilities for further investigation and not to create an unrealistic situation. So far as possible, therefore, subjects were treated at the local hospital as if they had been normally referred by local general practitioners. In any case, further detailed investigation of subjects identified in this way, most of whom had no definite gastrointestinal symptoms, is not easily justified, and can be easily misunderstood and possibly resented. However, almost all the women pund in this survey to have haemoglobin levels below $12 \mathrm{G}$. are involved in further epidemiological studies and will be followed for a considerable time.

With regard to the data relating to positive Hematests, it appears that much further work would need to be done to enable a "positive" result to be defined more clearly and to evaluate positive results, in particular with regard to their relevance to low haemoglobin levels in the community. Illingworth (1965) showed that the diet must be carefully controlled to a considerable degree before a positive Hematest is accepted as firm evidence of gastrointestinal bleeding, but even with careful dietary control Ross and Gray (1964) feel that "no value can be attached to the results of any of the chemical tests" for occult blood, and they feel it is questionable whether these tests should be retained in modern medicine. It is not felt justified in the present study to attempt to control the diets of the subjects in any way, but in spite of this and the view expressed by Ross and Gray (1964) the difference in the prevalence of positive tests in the subjects with haemoglobin levels bclow $12 \mathrm{G}$. and in those with haemoglobin levels of $12 \mathrm{G}$. or more, all of whom were tested in exactly the same way by "blind" observers, is of interest in an epidemiological context.

It was possible to examine aspirin-taking in these women, as questions relatıng to this had been asked routinely in the initial survey, and there was no evidence that the women with positive Hematests took aspirin more of ten than the other women. In fact the difference, though not significant, suggested the reverse. Interpretation of these data as they stand is therefore difficult, though it is of interest that our estimate of $16 \%$ positive tests in the women with lower haemoglobin levels is not very different from that obtained by Illingworth (1965) in 126 " normal people eating an unrestricted diet" $(21 \%$ quoted in text, $31 \%$ shown in Table). The results of this part of the study are therefore equivocal, but make it seem unlikely that serious underlying disorder is a causative factor of any magnitude in iron-deficiency anaemia in the community. The present data therefore give no support to the view that "in the adult (the basic disease process) is all too frequently a malignant tumour of the gastrointestinal tract" (Harris, 1963).

Backett (1960) has stressed that high-risk groups should be identified for screening procedures. In an approach to the community as a whole this would be achieved to some extent if the less healthy persuns more readily attended surveys such as the one described here than the rest of the community. The data presented here show that this is most unlikely to be the case in a survey for anaemia, as the persons who spontaneously attended the clinic differed from the basic population in none of the ways examined, other than in weight. It is difficult to interpret this difference in weight, but in the absence of any other significant difference it is unlikely to be of clinical importance.

Further data which bear indirectly on this aspect of bealth screening can be obtained by examining the trend in mean haemoglobin during the survey. If the women who attend a survey such as ours least readily are those with, on average, higher or lower haemoglobin levels, then the mean levels of successive groupe of subiects, examined in the order in which they attended, should show a rise or a fall. In fact the mean level of the last 67 women, most of whom required considerable persuasion to attend the survey, was $13.9 \pm 0.20 \mathrm{G}$., and though this is higher than the mean of the whole basic population (13.3 $\pm 0.05 \mathrm{G}$.) the difference is not significant. It appears likely, therefore, that neither the women who attend a survey most willingly nor those who attend most reluctantly differ with regard to their haemoglobin level from the population from which they come. In fact the absence of a real difference in the distributions by haemoglobin level had been predicted in view of the lack of evidence in an earlier community survey of a significant association between haemoglobin level and symptomatology (Woud and Elwood, 1966). In view of the fact that the symptoms examined in our study are not specific for iron deficiency, our data suggest that in any screening survey of the type we conducted high-risk groups are unlikely to atten 3 selectively to any important extent.

\section{Summary}

An evaluation of a community screening survey for anaemia has been made. This is based on the proportion of women found to have a low haemoglobin level in a large survey, the proportion of these found to have a serious underlying disorder, and the symptomatic benefit in them after iron therapy. In addition, the selection of women who voluntarily attend a screening survey is examined by comparing the distributions of a wide variety of variates in a large group of women who spontaneously attended the survey with these distributions in the whole community. These studies give very litule encouragement for ad hoc community screening.

\section{REPERENCES}

Abramson, J. H., Terespolsky, L., Brook, J. G., and Kark, S. L. (1965). Brit. 7. prev. soc. Med.. 19., 103. Acheson, R. M. (1963). Publ Hlth (Lond.), 77, 261

Backett, E. M (1960). Lancel, 2. 1075.

Bradhury F. C. S. (1948). Ibid., 2, 293.

Cochrane, A. L. (1951). In The Application of Scientific Methods to Industrial and Service Medicine, p. 97. Medical Research Couracti. H.M.S.O., London.

Elwond, P. C. (1964). Brit. 7. prev. soc. Med., 18, 81.

- and Wond, M. M. (1966). Ibid., 20, 172

Harris, J. W. (1963). The Red Cell. Cambridge, Mass.

Horne, W. A., Clark. J., and Parterson, W. J. (1967). Lancet, 1, 494

Horne, W. A., Clark. (1965). Gut. 6. 595.

Illingwotth, D. G. (1965). Gut. 6, 595. 1736.

Kilparrick, G. S. (1961). Bri: med. 7, 2, 1736.
Rawniley. K. (1966). F. psychosom. Res., 10, 84.

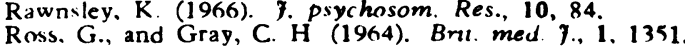

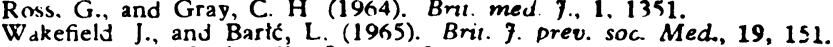

W'ilson, M. G (1963). Lancet, $2,51$.

Wood, M. M., and Elwood, P. C. (1966). Brit. F. prev. soc. Mied., 20 117. 